\title{
Evaluation of nursing students' attitudes and beliefs regarding sexual care
}

\author{
Hemșirelik öğrencilerinin cinsel bakıma ilișkin tutum ve \\ inançlarının değerlendirilmesi
}

Șefika Dilek Güven®, Gülden Küçükakça Çelik®

\section{ABSTRACT}

OBJECTIVE: The aim of this study was to explore nursing students' attitudes and beliefs towards sexual health care.

MATERIAL AND METHODS: The study design was quantitative descriptive. The study was conducted in nursing school of a university in Turkey between April-May 2018. 356 nursing students who volunteered to participate in the research formed the sample of the research. The data were collected using the "Data Collection Form" and the "Sexual Attitude and Beliefs Scale" (SABS).

RESULTS: In this study, the average scores of SABS for nursing students was $42.29 \pm 3.65$, when compared to the findings of other studies performed with nursing students in Turkey, in our study the sexual attitudes and beliefs of nursing students related to the sexual health care were more negative. In addition, this study also revealed the difference between attitudes and beliefs about sexual health care between the western and eastern countries and our country. Turkish nurses' attitudes and beliefs about sexual health care were more negative than Western countries. This result shows that our country still has its taboos on sexuality with respect to the West. In this study, the most important obstacle of Turkish nursing students about sexuality was "sexuality subject being too private to subject discuss with patients".

CONCLUSIONS: In order to provide holistic nursing care in Turkey, it is required to overcome these obstacles.

Keywords: Attitude and belief, sexual health care, nursing student, Turkey

\section{INTRODUCTION}

Sexuality is an important component of life and general health quality. As a requirement for holistic care, nurses cannot ignore the patient's sexual health needs. ${ }^{[1]}$ It is the duty of the nurse to give care about sexual health in order to

Nevşehir Hacı Bektaş Veli Üniversitesi, Semra ve Vefa Küçük Sağlık Bilimleri Fakültesi, Hemşirelik Bölümü, Nevşehir, Türkiye

\section{Yazısma Adresi/ Correspondence:}

Dr. Öğr. Üyesi Şefika Dilek Güven

Nevşehir Üniversitesi Semra ve Vefa Küçük Sağlık Bilimleri Fakültesi, Hemşirelik

Bölümü 50100 Nevşehir, Türkiye

Tel: $\quad$ +905393177016

E-mail: sdguven@nevsehir.edu.tr

Gelis/ Received: $\quad 09.07 .2020$

Kabul/ Accepted: 15.08 .2020

\section{öz}

AMAÇ: Araştırmanın amacı hemşirelik öğrencilerinin hastaların cinsel bakımına ilişkin tutum ve inançlarını belirlemektir.

GEREÇ VE YÖNTEMLER: Çalışma nicel tanımlayıcı tasarımda, NisanMayıs 2018 tarihleri arasında Türkiye'de bir üniversitenin hemşirelik okulunda yapıldı. Araştırmanın örneklemini araştırmaya katılmaya gönüllü 356 hemşirelik öğrencisi oluşturdu. Araştırmada veriler "Veri Toplama Formu" ve "Cinsel Tutum ve İnanç Ölçeği” (SABS) kullanılarak toplandı.

BULGULAR: Bu çalışmada hemşirelik öğrencilerinin SABS puan ortalaması 42,29 $\pm 3,65$ idi, Türkiye'de hemşirelik öğrencileriyle yapılan diğer çalışma bulgularına göre bizim çalışmamızda hemşirelik öğrencilerinin cinsel bakıma ilişkin tutum ve inançları daha olumsuzdu. Ayrıca bu çalışma batı ve doğu ülkeleri ile Ülkemiz arasında cinsel bakıma ilişkin tutum ve inançlar arasındaki farkı da ortaya koydu. Türk hemşirelerinde batı ülkelerine göre cinsel bakımına ilişkin tutum ve inançlar daha olumsuzdu. Bu sonuç ülkemizin batıya göre cinsellik konusunda hala tabularının olduğunu göstermektedir. Bu çalışmada Türk hemşirelik ögrencilerinin cinsellik hakkında en önemli engeli "cinsellik hastalarla tartışmak için çok özel bir konu" idi.

SONUÇ: Türkiye'de hemşirelerin bütüncül bakım hizmeti sunabilmeleri için bu engellerin aşılması gerekmektedir.

Anahtar Kelimeler: Tutum ve inanç, cinsel sağlık bakımı, hemşirelik ögrrencisi, Türkiye increase the quality of life for the patients. ${ }^{[2]}$ The roles of the nurse in sexual health care include assessing sexual health, identifying the problem, solving the problem with appropriate nursing interventions, and maintaining sexual health. ${ }^{[3]}$

Sexuality and sexual health of a patient are affected by many factors such as individual perceptions, relationship with the partner, age, level of knowledge, marital status, opportunities, values, social, spiritual and cultural norms, physical and mental health. The decline in the individual's health condition, diseases and treatments negatively affect the sexuality. ${ }^{[4]}$ Unsolved sexual problems can affect individual's quality of life, interpersonal relationships, and even treatment compliance. ${ }^{[5]}$ However, the sexual problems of the patients are neglected in the health service 
provision. When sexual health of the patients is neglected, the quality of lives of patients is negatively affected by cumulative problems and problems related to sexual issues. ${ }^{[6]}$ Although assessment of sexual health and counseling on sexual health are in the scope of the responsibility of the nurse, it is stated that the nurses do not routinely assess the sexuality of the patient and provide very little counseling. ${ }^{\left[{ }^{[7]}\right.}$

While nurses provide sexual health care for holistic care, they encounter many obstacles originating from factors related to themselves and the patients. The obstacles related to the nurses themselves are their time constraints, limited sexual information, communication difficulties due to sensitive issues, their low self-esteem, religious and cultural values. Patient-related obstacles were identified to be anxiety about being misunderstood by patients, age, gender, race, cultural and religious values of patients. These obstacles should be overcome in order to provide holistic care. ${ }^{[8]}$

Perspectives and attitudes of nurses who are with the individual at every stage of the health system are extremely important in terms of providing quality services to patients regarding sexuality. ${ }^{[9]}$ Sexuality attitude varies according to one's society, religious beliefs and culture. ${ }^{[10]}$ Personal sexual attitudes affect especially the implementation of sexual counselling services. ${ }^{[11]}$ Negative attitudes and beliefs affect the nurse's evaluation of the sexual problem of the individual and providing consultancy for this. ${ }^{[12]}$ Neglecting sexual health needs and not providing adequate services cause many biopsychosocial problems that result in mortality and morbidity. ${ }^{[13]}$ In order for nurses to provide sexual care, they must first realize their own sexual attitudes and how these attitudes affect care.

Nursing education plays an important role in the preparation of nursing students so that they can provide sexual health care in the future. In order to provide holistic care, it is necessary for the nurses to improve their knowledge, skills and abilities about sexual health care during their training. ${ }^{[2]}$ In addition, nursing students need to be trained to provide them with a positive attitude and belief for sexual health care. Attitudes and beliefs about sexual health care influence the behavior of the nurse. ${ }^{[14]}$ Determining the attitudes and beliefs of nursing students towards sexual health care is important to determine how they give support best in this issue. This research was conducted to determine the attitudes and beliefs of nursing students about sexual health care.

\section{MATERIAL AND METHODS}

\section{Aim}

The aim of this study was to explore nursing students' attitudes and beliefs towards sexual health care.

\section{Design}

A quantitative cross-sectional descriptive study design was used to explore nursing students' attitudes and beliefs towards sexual health care of the patients.

\section{Participants}

The study was conducted in nursing school of a university in Turkey's Central Anatolia region between April-May 2018. 356 nursing students who volunteered to participate in the research formed the sample of the research.

\section{Instruments}

\section{Data Collection Form}

The information on the sociodemographic and sexual health care characteristics of the student nurses was questioned in the data collection form.

\section{Sexual Attitude and Beliefs Scale (SABS)}

SABS, developed by Reynolds and Magnan in 2005 was translated into Turkish, validity and reliability were performed in 2010 by Ayhan et al. In the study of Ayhan et al. (2010) Cronbach's alpha value was determined to be 0.73 and this study it was determined to be 0.78 . The scale consists of 12 items. Participants make markings on a 6 (six)-point Likert type scale for each item. Each item of the scale is evaluated separately. Six of the 12 items $(1,2,4,6,8,10,12$ items) are scored inversely to avoid bias that can occur when marking the scale. The total score of the scale ranges from 12 to 72. Both the total scale score and the high item scores indicate that the negative attitudes and beliefs regarding sexual health care have increased. Increase in negative attitudes and beliefs also negatively affects the ability of the nurses to assess the sexual problem of the individual and counsel accordingly. The expressions in the scale, after the inversion process is performed; are turned into dichotomous data as "I agree" for expressions with points (1), (2) and (3) and "I disagree" for expressions with points (4), (5) and (6). ${ }^{[12,15]}$

\section{Data Collection}

After the students were informed, data collection forms were distributed. Students gathered after completing the data collection forms.

\section{Ethical Considerations}

The research was conducted through ethical permission of the university where the research was conducted and the permission of the institution. Before starting the research, 
the students were informed about the purpose of the research and the data collection tools to be used and their approvals were obtained.

\section{Data Analysis}

Analysis of the data was performed with the help of SPSS 20 packaged software. The normal distribution fitness of the parameters was assessed by the Shapiro Wilks test. Data of the research were analyzed using descriptive statistical methods, Mean, Standard deviation, Frequency, Mann-Whitney $\mathrm{U}$ and Kruskal-Wallis tests in comparison between two groups. Significance value was taken to be $\mathrm{p}<0.05$.

\section{RESULTS}

The average age of participants was $21.00 \pm 2.00,73.6 \%$ of them were female and $3.7 \%$ of them were married (Table 1 ).

Table 1. Characteristics of nursing student $(n=356)$

\begin{tabular}{lcc}
\hline Characteristics & $n$ & $\%$ \\
\hline Gender & 262 & 73.6 \\
Female & 94 & 26.4 \\
Male & 73 & 20.5 \\
\hline Class & 90 & 25.3 \\
1 & 97 & 27.2 \\
2 & 96 & 27.0 \\
3 & 13 & 3.7 \\
4 & 343 & 96.3 \\
Marital status & Mean \pm SD & $21.00 \pm 2.00$ \\
Married & & \\
Single & &
\end{tabular}

SABS point average of the participants is $42.29 \pm 3.65$, which is approximately 6.5 points higher than the total point average (36) of the scale. In this study, the mean SABS score of each item ranged from 1.94 to $4.90 .89 .3 \%$ of the nursing students agree that the discussion of sexuality is necessary for the health of the patient, $88.2 \%$ consider that the diseases and treatments can affect the sexuality of the patients and $84.8 \%$ think that it is a nursing responsibility to allow the patient to talk about sexual problems. The SABS scores of these three positive items, which student nurses agreed on most, were; $1.94 \pm 1.02,2.48 \pm 1.15$, and $2.17 \pm 1.14$, respectively. It was also found out that $68.0 \%$ of the student nurses thought that discussing sexuality with patients was a very private subject, $48.3 \%$ of the student nurses were uncomfortable about talking about the subject related to the sexuality, and $44.4 \%$ of the student nurses thought that hospitalized patients were too sick to consider sexuality. The SABS scores of these three negative items, which student nurses agreed on most, were; $4.90 \pm 0.80,4.67 \pm 0.72,4.79 \pm 0.76$ (Table 2).

As a result of the statistical analysis, it was found out that there was no significant difference between SABS point average and gender $(p>0.05)$ and there was a significant difference between SABS point average and class $(\mathrm{p}<0.05)$ (Table 3$)$.

\section{DISCUSSION}

It is very important to evaluate the sexuality of the patients for holistic care. For this reason, nursing students need to graduate with the ability to evaluate sexuality and provide sexual health care. ${ }^{[2,16]}$ The high score on SABS indicates

Table 2. Nursing students' attitudes and belief regarding sexuality care in patients

\begin{tabular}{|c|c|c|c|}
\hline Items & Mean $\pm S D$ & Agreement (\%) & Disagreement (\%) \\
\hline \multicolumn{4}{|l|}{ Positively stated item } \\
\hline Giving a patient permission to talk about sexual concerns is a nursing responsibility & $2.17 \pm 1.14$ & 84.8 & 15.2 \\
\hline I feel confident in my ability to address patients' sexual concerns & $2.96 \pm 1.17$ & 59.0 & 41.0 \\
\hline I understand how my patients' diseases and treatments might affect their sexuality & $2.48 \pm 1.15$ & 88.2 & 11.8 \\
\hline I make time to discuss sexual concerns with my patients & $2.99 \pm 1.13$ & 56.5 & 43.5 \\
\hline $\begin{array}{l}\text { I am more comfortable talking about sexual issues with my patients than are most } \\
\text { of the nurses I work with }\end{array}$ & $2.78 \pm 1.20$ & 48.3 & 51.7 \\
\hline Discussing sexuality is essential to patients' health outcomes & $1.94 \pm 1.02$ & 89.3 & 10.7 \\
\hline Patients expect nurses to ask about their sexual concerns & $2.91 \pm 1.18$ & 56.7 & 43.3 \\
\hline \multicolumn{4}{|l|}{ Negatively stated item } \\
\hline I am uncomfortable talking about sexual issues & $4.67 \pm 0.72$ & 48.3 & 51.7 \\
\hline Most hospitalized patients are too sick to be interested in sexuality & $4.79 \pm 0.76$ & 44.4 & 55.6 \\
\hline Sexuality is too private subject to discuss with patients & $4.90 \pm 0.80$ & 68.0 & 32.0 \\
\hline Sexuality should be discussed only if initiated by the patient & $4.83 \pm 0.76$ & 36.8 & 63.2 \\
\hline $\begin{array}{l}\text { Whenever patients ask me a sexually related question, I advise them to discuss the } \\
\text { matter with their physician }\end{array}$ & $4.82 \pm 0.74$ & 40.1 & 59.9 \\
\hline Total SABS scores & Mean \pm SD & \multicolumn{2}{|c|}{$42.29 \pm 3.65$} \\
\hline
\end{tabular}


Table 3. The relationships the nursing students' characteristics among total SABS scores

\begin{tabular}{|c|c|c|}
\hline Characteristics & $n(\%)$ & Mean $\pm S D$ \\
\hline \multicolumn{3}{|l|}{ Gender } \\
\hline Female & $262(73.6)$ & $42.28 \pm 3.63$ \\
\hline Male & $94(26.4)$ & $42.31 \pm 3.72$ \\
\hline Test and $p$ value & $-0.331^{+}$ & 0.741 \\
\hline \multicolumn{3}{|l|}{ Class } \\
\hline 1 & $73(20.5)$ & $42.75 \pm 3.68$ \\
\hline 2 & $90(25.3)$ & $41.51 \pm 3.62$ \\
\hline 3 & $97(27.2)$ & $42.82 \pm 3.85$ \\
\hline 4 & $96(27.0)$ & $42.14 \pm 3.34$ \\
\hline Test and $p$ value & $8.038^{++}$ & $p=0.045$ \\
\hline \multicolumn{3}{|l|}{ Age } \\
\hline 18 & $13(3.7)$ & $44.38 \pm 3.42$ \\
\hline 19 & $66(18.5)$ & $41.90 \pm 3.97$ \\
\hline 20 & $72(20.2)$ & $41.77 \pm 3.56$ \\
\hline 21 & 70 (19.7) & $42.58 \pm 3.79$ \\
\hline 22 & 68 (19.1) & $41.94 \pm 3.20$ \\
\hline 23 & $43(12.1)$ & $42.90 \pm 3.65$ \\
\hline 24 & $13(3.7)$ & $42.76 \pm 2.80$ \\
\hline$\geq 25$ & $11(3.1)$ & $42.90 \pm 4.57$ \\
\hline Test and $p$ value & $10.414^{++}$ & $p=0.166$ \\
\hline \multicolumn{3}{|l|}{ Marital status } \\
\hline Married & $13(3.7)$ & $43.00 \pm 3.39$ \\
\hline Single & $343(96.3)$ & $42.26 \pm 3.66$ \\
\hline Test and $p$ value & -1.233 & 0.218 \\
\hline
\end{tabular}

that negative attitudes and beliefs about sexual health care increased. ${ }^{[12]}$ In the studies conducted with Turkish nursing students, the mean SABS score of the nursing students was determined to be $41.55 \pm 7.65$ (13), $30.62 \pm 6.37$ (7) and $34.88 \pm 1.11 .{ }^{[15]}$ In this study, the average SABS score of the nursing students was $42.29 \pm 3.65$, which was approximately 6.5 points higher than the total point average of the scale (36). With respect to the findings of other studies conducted with nursing students in Turkey, in our study the attitudes and beliefs of nursing students related to the sexual health care are more negative. Negative attitudes and beliefs can negatively affect student nurses' ability to assess the sexual issues of the individual and counsel accordingly. In addition, this study also shows the difference between attitudes and beliefs about sexual health care between Western and Eastern countries and our country. The attitudes and beliefs of Turkish nursing students regarding sexual health care were more negative than nursing students in Canada ${ }^{[14]}$, Canadian nurses ${ }^{[17]}$, Swedish nurses ${ }^{[18]}$ and it was more positive than Chinese nurses. ${ }^{[19,20]}$ These results show that our country still has taboos about sexuality with respect to the West. For this reason, this situation shows that the nurses of our country cannot adequately assess the sexuality of the patients, indicating that this is an obstacle to holistic care.

In this study, the most important obstacle of Turkish nursing students about sexuality was "sexuality being a too private subject to discuss with the patients". The ideas of Turkish nurses ${ }^{[8]}$ "they feel uncomfortable while talking about the subject", the ideas of Turkish nursing students ${ }^{[21]}$ that "they think that most of the hospitalized patients are too sick to consider sexuality", the ideas of nurses in Sweden and China ${ }^{[19,20]}$ that "sexuality is a too private subject to discuss with patients", the ideas of Canadian nursing students ${ }^{[9]}$ that " the patients expect nurses to ask about their sexual problems" were determined to be the most important obstacles. Also, in our study, the last obstacle of Turkish nursing students about sexuality was determined as "sexuality should be discussed only if initiated by the patient". Despite being the last obstacle, $36.8 \%$ of the nursing students were participating in this obstacle. This suggests that the nurse will not initiate a dialogue about the sexuality of the patient, so that sexual care cannot be initiated when the sexuality discussion is not initiated by the patient. When compared to other studies, our study revealed that there are differences between the factors considered as the most important obstacle. This situation suggests that nurses have different attitudes towards sexual counseling. We can say that this difference is caused by the sexuality being affected by the religious and cultural values of societies, and the political and economic conditions.

While nurses provide the patients with sexual health care for holistic care, they encounter many obstacles resulting from factors related to themselves and patients. ${ }^{\left[{ }^{8]}\right.}$ While $12.1 \%$ of nursing students in Canada ${ }^{[14]}$ and $62.0 \%$ of Turkish nursing students ${ }^{[21]}$ stated that discussing sexuality is necessary for the health of the patient, in our study $89.3 \%$ of the Turkish nursing students stated that discussing sexuality is necessary for the health of the patient. This suggests that the Turkish nursing students believe that they believe in the necessity of sexual health care, but that the most important barrier to sexuality is the barrier to providing holistic care services because they think of sexuality as a very private subject to discuss with patients. This is probably due to the fact that sexuality in Turkey is a cultural and religious taboo. In order to provide holistic care, nurses in Turkey require to overcome these obstacles. In this study, the expression "I am more comfortable talking about sexual issues with my patients than are most of the nurses I work with" was the expression that Turkish nursing students least participated in from positive statements 
regarding sexual care (48.3\%). Although it is the expression that they agree with the least, almost half of its students are pleased to show that they do not have any obstacles in speaking sexuality.

When they were working with health science students, Areskoug-Josefsson et al. (2016) ${ }^{[22]}$, Pynor et al. (2005) ${ }^{[23]}$ and Wittkopf et al. (2018) ${ }^{[24]}$ reported that female students were more likely to feel uncomfortable than male students when they were dealing with sexual problems. They pointed out that this disparity may be due to differences in male and female sexual behaviors. In the results of this study, SABS scores of the female $(42.28 \pm 3.63)$ and male $(42.31 \pm 3.72)$ students were similar and the attitudes and beliefs regarding sexual health care of both genders were negative. The similar negative attitudes and beliefs about sexual health care in Turkish nursing students suggest that both genders do not feel comfortable while giving sexual health care. This result of our study emphasizes that Turkish nursing students should be supported by teaching methods during their education which make them feel comfortable while giving sexual health care.

Since as the level of education increases, knowledge and experience related with sexual health care will increase, it is then expected that attitudes and beliefs about sexual health care will also change in a positive manner. Nursing education should not only inform about sexuality, but should also provide the nurse with the ability to assess the patient's sexuality and be equipped with communication skills to address their problems. ${ }^{\left[{ }^{[]}\right.}$In this study, the attitudes and beliefs of the fourth grade students regarding the sexual health care were more positive than those of the other grades. It was a surprising result of this study that the attitudes and beliefs regarding sexual health care were more negative in third grade at the school where this study was conducted than the other grades, even though they have sexuality and sexual health education in Obstetric and Gynecologic class in the third grade. Contrary to our study, in the study of Bal and Sahiner (2015) ${ }^{[21]}$, it was determined that the attitudes and beliefs of third grade Turkish nursing students regarding sexual health care were more positive than the other grades.

\section{CONCLUSIONS}

The study findings show that the attitudes and beliefs of nursing students regarding sexual health care were negative and they had their obstacles. In order to provide holistic nursing care in Turkey, it is required to overcome these obstacles. Teachers should support the students during the nursing education in order to develop positive attitudes and beliefs about sexuality.

\section{Ethics Committee Approva}

The study was approved by Nevşehir Hacı Bektaş Veli University Ethics Committee. (date and number of approval: 2018.06.68).

Peer-review

Externally peer-reviewed.

Conflict of Interest

No conflict of interest was declared by the authors.

Financial Disclosure

No financial support has been received.

\section{REFERENCES}

1. Kong SKF, Wu LH, Loke AY. Nursing students' knowledge, attitude and readiness to work for clients with sexual health concerns. J Clin Nurs 2009;18:2372-82. [CrossRef]

2. Sung SC, Lin YC. Effectiveness of the sexual healthcare education in nursing students' knowledge, attitude, and self-efficacy on sexual healthcare. Nurs Educ Today 2013;33:498-503. [CrossRef]

3. Kütmeç C. Kadınlarda cinsel fonksiyon bozukluğu ve hemşirelik bakımı [Sexual dysfunction and nursing care in women]. Firat Sağlık Hizmetleri Derg 2009;4:111-36.

4. Atlı ÖA, Gürhan N, Duyan V. An evaluation of sexual attitudes of nursing students in Turkey. J Psy Nurs 2016;7:114-20. [CrossRef]

5. Southard NZ, Keller J. The importance of assessing sexuality: A patient perspective. Clin J Oncol Nurs 2009;13:213-7. [CrossRef]

6. Algier L, Kav S. Nurses' approach to sexuality-related issues in patients receiving cancer treatments. Turk J Cancer 2008;38:13541. http://www.turkjcancer.org/pdf/pdf_TJC_491.pdf

7. Tugut N, Golbasi Z. Sexuality assessment knowledge, attitude, and skill of nursing students: an experimental study with control group. Int J Nurs Knowl 2018;28:123-30. [CrossRef]

8. Bal MD. Hemşirelerin cinsel bakıma ilişkin tutum ve inançları [Nurses' Attitudes and Beliefs about Sexual Health Care]. Hemşirelikte Eğitim ve Araştırma Derg 2014;11:38-42. https:// jag.journalagent.com/kuhead/pdfs/KUHEAD_11_3_38_42.pdf

9. Kuczynski HJ. Nursing and medical students'sexual attitudes and knowledge curricular implications. JOGN Nurs 2006;9:339-42. [CrossRef]

10. Meston CM, Bradford A. Sexual dysfunctions in women. Annu Rev Clin Psychol 2007;3:233-56. [CrossRef]

11. Ören B, Zengin N, Yazıcı S, Akıncı, AÇ. Attitudes, beliefs and comfort levels of midwifery students regarding sexual counselling in Turkey. Midwifery 2018;56:152-7. [CrossRef]

12. Reynolds KE, Magnan MA. Nursing attitudes and beliefs toward human sexuality, collaborative research promoting evidence-based practice. Clin Nurse Spec 2005;19:255-9. [CrossRef]

13. Haboubi N, Lincoln N. Views of health professionals on discussing sexual issues with patients. Disabil Rehabil 2003;25:291-6. [CrossRef]

14. Magnan MA, Norris DM. Nursing students' perceptions of barriers to addressing patient sexuality concerns. J Nurs Educ 2008;47:260 8. [CrossRef]

15. Ayhan H, Iyigun E, Tastan S, Coskun H. Turkish version of the reliability and validity study of the Sexual Attitudes and Belief Survey. Sex Disabil 2010;28:287-96. [CrossRef]

16. Tsai LY, Huang CY, Liao WC, Tseng TH, Lai TJ. Assessing student nurses' learning needs for addressing patients' sexual health concerns in Taiwan. Nurs Educ Today 2013;33:152-9. [CrossRef]

17. Magnan MA, Reynolds K. Barriers to addressing patient sexuality concerns across five areas of specialization. Clin Nurs Spec 2006;20:285-92. [CrossRef] 
18. Saunamäki N, Andersson M, Engström M. Discussing sexuality with patients: nurses' attitudes and beliefs. J Adv Nurs 2010;66:130816. [CrossRef]

19. Zeng YC, Li Q, Wang N, Ching SS, Loke AY. Chinese nurses' attitudes and beliefs toward sexuality care in cancer patients. Cancer Nurs 2011;34:E14-20. [CrossRef]

20. Zeng YC, Liu X, Loke AY. Addressing sexuality issues of women with gynaecological cancer: chinese nurses' attitudes and practice. J Adv Nurs 2012;68:280-92. [CrossRef]

21. Bal MD, Sahiner NC. Turkish Nursing Students' Attitudes and Beliefs Regarding Sexual Health. Sex Disabil 2015;33:223-31. [CrossRef]
22. Areskoug-Josefsson K, Larsson A, Gard G, Rolander B, Juuso P. Health care students' attitudes towards working with sexual health in their professional roles: survey of students at nursing, physiotherapy and occupational therapy programmes. Sex Disabil 2016;34:289-302. [CrossRef]

23. Pynor R, Weerakoon P, Jones MK. A preliminary investigation of physiotherapy students' attitudes towards issues of sexuality in clinical practice. Physiotherapy 2005;91:42-48. [CrossRef]

24. Wittkopf PG, Sousa TR, Cardoso FL, Sperandio FF. Assessment of Knowledge, Comfort and Attitudes of Physiotherapy Students Towards Human Sexuality. Sex Disabil 2018;36:195-203. [CrossRef] 